\title{
Genome-wide association study (GWAS) for morphological and yield-related traits in an oil palm hybrid (Elaeis oleifera $x$ Elaeis guineensis) population
}

\author{
Jaime A. Osorio-Guarín', Gina A. Garzón-Martínez', Paola Delgadillo-Duran', Silvio Bastidas², Leidy P. Moreno², \\ Felix E. Enciso-Rodríguez ${ }^{1}$ Omar E. Cornejo ${ }^{3^{*}}$ and Luz Stella Barrero ${ }^{{ }^{*}}$
}

\begin{abstract}
Background: The genus Elaeis has two species of economic importance for the oil palm agroindustry: Elaeis oleifera $(\mathrm{O})$, native to the Americas, and Elaeis guineensis $(\mathrm{G})$, native to Africa. This work provides to our knowledge, the first association mapping study in an interspecific OxG oil palm population, which shows tolerance to pests and diseases, high oil quality, and acceptable fruit bunch production.

Results: Using genotyping-by-sequencing (GBS), we identified a total of 3776 single nucleotide polymorphisms (SNPs) that were used to perform a genome-wide association analysis (GWAS) in 378 OxG hybrid population for 10 agronomic traits. Twelve genomic regions (SNPs) were located near candidate genes implicated in multiple functional categories, such as tissue growth, cellular trafficking, and physiological processes.

Conclusions: We provide new insights on genomic regions that mapped on candidate genes involved in plant architecture and yield. These potential candidate genes need to be confirmed for future targeted functional analyses. Associated markers to the traits of interest may be valuable resources for the development of markerassisted selection in oil palm breeding.
\end{abstract}

Keywords: Association mapping, Elaeis guineensis, Elaeis oleifera, Genotyping-by-sequencing, Plant architecture, Yield

\section{Background}

The oil palm is an important crop that has a higher quality oil and a greater yield potential compared to other oil-producing crops [1]. Colombia is the fourthlargest oil palm producer worldwide with 1.8 million tons produced for the year 2018 and a yield of 3.8 tons/ ha, placing the country above the average global yield [2]. Within the Arecaceae family, the African oil palm (Elaeis guineensis), native to West Africa, is the primary source of most of the vegetable oil found worldwide [3]. However, another palm species known as the American

\footnotetext{
* Correspondence: omar.cornejo@wsu.edu; Ibarrero@agrosavia.co

${ }^{3}$ School of Biological Sciences, Washington State University, Pullman, WA, USA

${ }^{1}$ Tibaitatá Research Center, Corporación Colombiana de Investigación Agropecuaria, Agrosavia, Bogotá, Colombia

Full list of author information is available at the end of the article
}

oil palm (Elaeis oleifera), which is native to the tropics of Central and South America, is recognized for its high yield production [3]. Both palm species are perennial monocots with lifespans of approximately 25 years [4], which results in slow breeding processes. The Corporación Colombiana de Investigación Agropecuaria (Agrosavia) established a breeding program focused on developing OxG interspecific hybrids (E. oleifera $x$ E. guineensis). The OxG is characterized by having slow trunk growth [5], tolerance to bud rot [6-9], and red ring diseases [10] in comparison to the parent species. Additionally, these OxG populations inherited the parthenocarpic fruit development of E. oleifera, which allows the production of seedless fruits [11].

Saturated genetic linkage maps are essential for the identification of genomic regions associated with major genes and with quantitative trait loci (QTLs) that control 
agronomic traits. Over the last 20 years, multiple genetic maps of the oil palm have been constructed. The first such map was generated using restriction fragment length polymorphisms (RFLPs) and amplified fragment length polymorphisms (AFLPs) [12, 13]. Dense genetic maps were subsequently constructed using simple sequence repeats (SSRs) and single nucleotide polymorphism (SNP) markers, which have also been used for QTL identification. Using this approach, Jeennor and Volkaert [14] identified a QTL associated with bunch weight using a mapping population of 69 accessions and generated a genetic map with 89 SSRs and 101 SNPs. Further, Billotte et al. [15] used a multi-parent linkage map elaborated with 251 SSRs and reported QTLs associated with bunch traits. Similar approaches have enabled the identification of 164 QTLs associated with 21 oil yield components using SSR, AFLP, and RFLP markers [16].

In recent years, advances in next-generation sequencing technology have lowered DNA sequencing costs and thousands of SNPs have now been obtained [17, 18]. In particular, genotyping-by-sequencing (GBS) is a rapid, low-cost, and robust approach for screening breeding populations using SNPs [19]. Pootakham et al. [20] constructed an oil palm map using an $\mathrm{F}_{2}$ population and 1085 SNPs derived from GBS and were able to identify QTLs for height and fruit bunch weight. Similarly, a genomewide association analysis (GWAS), using a larger number of SNPs (4031) derived from GBS across a diverse panel of E. guineensis, allowed the identification of novel QTLs associated with the increase in trunk height [21].

GWAS has been proposed as a much more robust approach compared to QTL linkage mapping [22]. The use of a wide range of genetic backgrounds in GWAS analyses increases the probability of detecting QTL regions associated with traits of interest, compared to the limited genetic variation of a bi-parental mapping population [23]. However, the limitations of GWAS, such as the effect of population structure, can lead to spurious associations between a candidate marker and a specific phenotypic trait [24]. To eliminate such association, the mixed linear model incorporates structure data $(\mathrm{Q})$ and relative kinship effects $(\mathrm{K})$, resulting in the reduction of false-positive associations [25].

Given palm oil's use in numerous prepared foods and industrial and medical applications, the economic importance of this crop has experienced rapid growth and palm oil is now the second most traded vegetable oil world-wide after soybean [26, 27]. The demand for this crop is increasing due to a shift away from trans-fats to healthier alternatives [28], and because its residues can be processed to produce biofuel [27]. For these reasons, the identification of specific genomic regions whose genes are involved in morphological traits, such as height and foliar area, and the relationship between these traits and productivity, is becoming increasingly important for this crop.

Although previous studies have identified QTLs controlling morphological and yield-related traits in oil palm, these QTLs were detected using intraspecific populations. Our study is the first report in which molecular markers have been mapped through association analysis in an interspecific OxG population. Our study aims were: (i) genotype an OxG oil palm mapping population; and (ii) perform GWAS to identify loci or candidate genes involved in morphological and yield-related traits for future use in breeding programs.

\section{Results}

\section{Analysis of phenotypic data}

Means, standard deviations, and range values of the phenotypic data for the population of 378 OxG hybrids are shown in Table 1. The first principal component (PC1) explained $45.6 \%$ of the total phenotypic variation, where morphological-related traits, such as leaf area (LA), foliar area (FA), leaf dry weight (LDW), and trunk height (HT) contributed extensively to this component. Meanwhile, the second principal component (PC2) explained $19.9 \%$ of the variance, associated mainly with

Table 1 Mean values, standard deviations (SD) and minimum and maximum values of the phenotypic traits used in this study

\begin{tabular}{|c|c|c|c|c|c|c|c|}
\hline Category & Trait & Abbreviation & Unit & Mean & SD & Minimum value & Maximum value \\
\hline \multirow[t]{7}{*}{ Morphological } & Trunk Diameter & TD & $\mathrm{cm}$ & 88.5 & 6.0 & 62.4 & 102.0 \\
\hline & Trunk Height & $\mathrm{HT}$ & $\mathrm{cm}$ & 250.3 & 29.5 & 133.3 & 327.0 \\
\hline & Rachis Length & $\mathrm{RL}$ & $\mathrm{cm}$ & 421.5 & 35.3 & 275.5 & 530.0 \\
\hline & Leaf Dry Weight & LDW & $\mathrm{kg}$ & 2.2 & 0.3 & 1.3 & 3.7 \\
\hline & Foliar Area & FA & $m^{2}$ & 385.0 & 78.2 & 141.3 & 617.1 \\
\hline & Leaf Area & LA & $\mathrm{m}^{2}$ & 8.6 & 1.3 & 4.7 & 12.7 \\
\hline & Leaflet per Leaf & LXL & unit & 234.8 & 14.8 & 184.0 & 294.0 \\
\hline \multirow[t]{3}{*}{ Yield } & Bunch Weight & BW & $\mathrm{kg}$ & 6.1 & 1.8 & 1.0 & 19.5 \\
\hline & Bunch Number & $\mathrm{BN}$ & unit & 8.8 & 5.0 & 1.0 & 27.0 \\
\hline & Yield per Palm & Yield & kg & 56.5 & 39.1 & 1.8 & 233.0 \\
\hline
\end{tabular}


yield-related traits (Fig. 1a-b). Positive correlations were observed between most of the morphological traits $(r=$ 0.1 to 0.8 ), while lower correlation values were found between yield and most of the morphological traits $(r \leq$ 0.3) (Fig. 1b). Notably, HT was correlated with FA, LA, LDW and trunk diameter (TD) $(r \geq 0.6)$, whereas yield was highly correlated with bunch number (BN) $(r=$ $0.91)$; furthermore, it also showed a weaker correlation with bunch weight (BW) $(r=0.57)$.

A hierarchical cluster analysis was performed to evaluate the phenotypic similarity among the 378 OxG hybrids (Fig. 2; Additional file 1: Table S1). We found phenotypic differences between the two clusters to agree with the variability of the morphological-related traits. Overall, Group II showed the highest mean values for all the morphological-related traits (Additional file 3: Figure S1), e.g., OxG individuals from Group II were significantly taller $(\mathrm{HT}=269 \pm 21 \mathrm{~cm})$ compared to OxG from Group I $(\mathrm{HT}=$ $238 \pm 28 \mathrm{~cm})(p \leq 0.0001)$. However, yield-related traits had no significant differences between groups.

\section{SNP calling}

A total of 1,058,182,456 raw Illumina sequencing reads from seven Illumina HiSeq lanes were generated

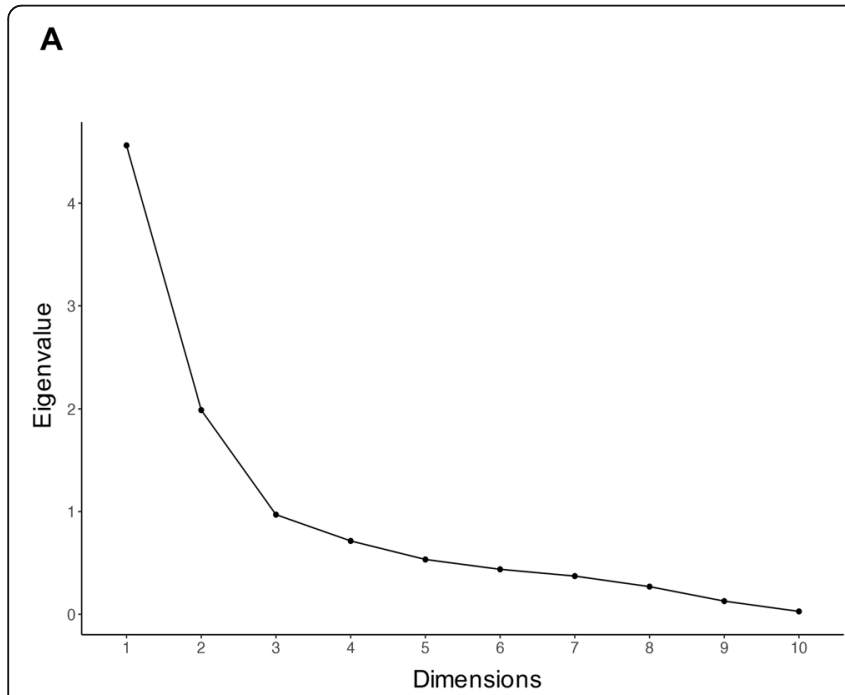

B

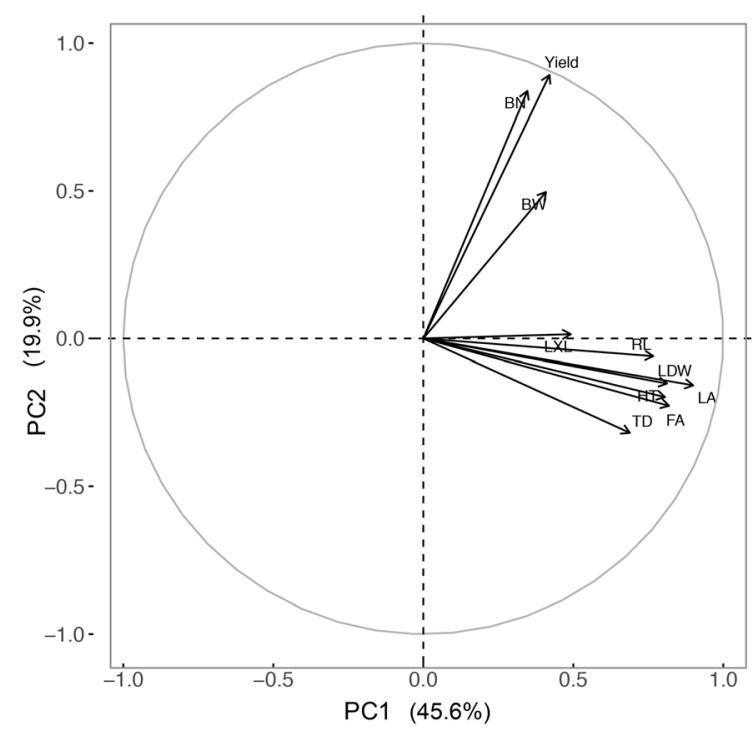

C

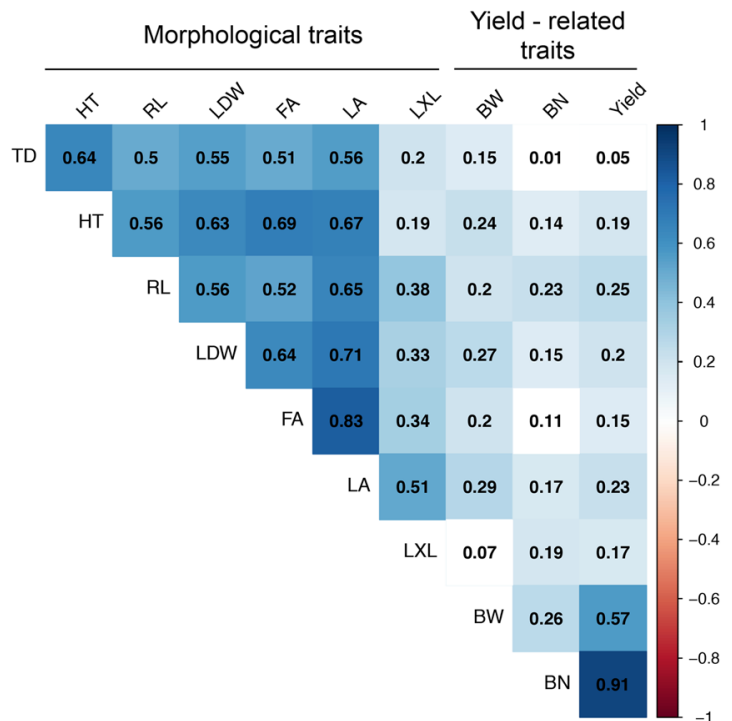

Fig. 1 a Scree plot calculated across 10 traits for a population of 378 E. oleifera $x$ E. guineensis (OxG) individuals; b Principal components loading plot for the population of 378 OxG for PC1 \& PC2 calculated across 10 traits; c Correlation among 10 traits of the 378 OxG. TD =Trunk Diameter, $H T=$ Trunk Height, RL = Rachis Length, LDW = Leaf Dry Weight, FA = Foliar Area, LA = Leaf Area, LXL = Leaflet per Leaf, BW = Bunch Weight, BN= Bunch number, and Yield $=$ Yield per Palm. Color boxes indicate significant correlations $(p \leq 0.01)$, and white boxes indicate coefficients with $p \geq 0.01$ 


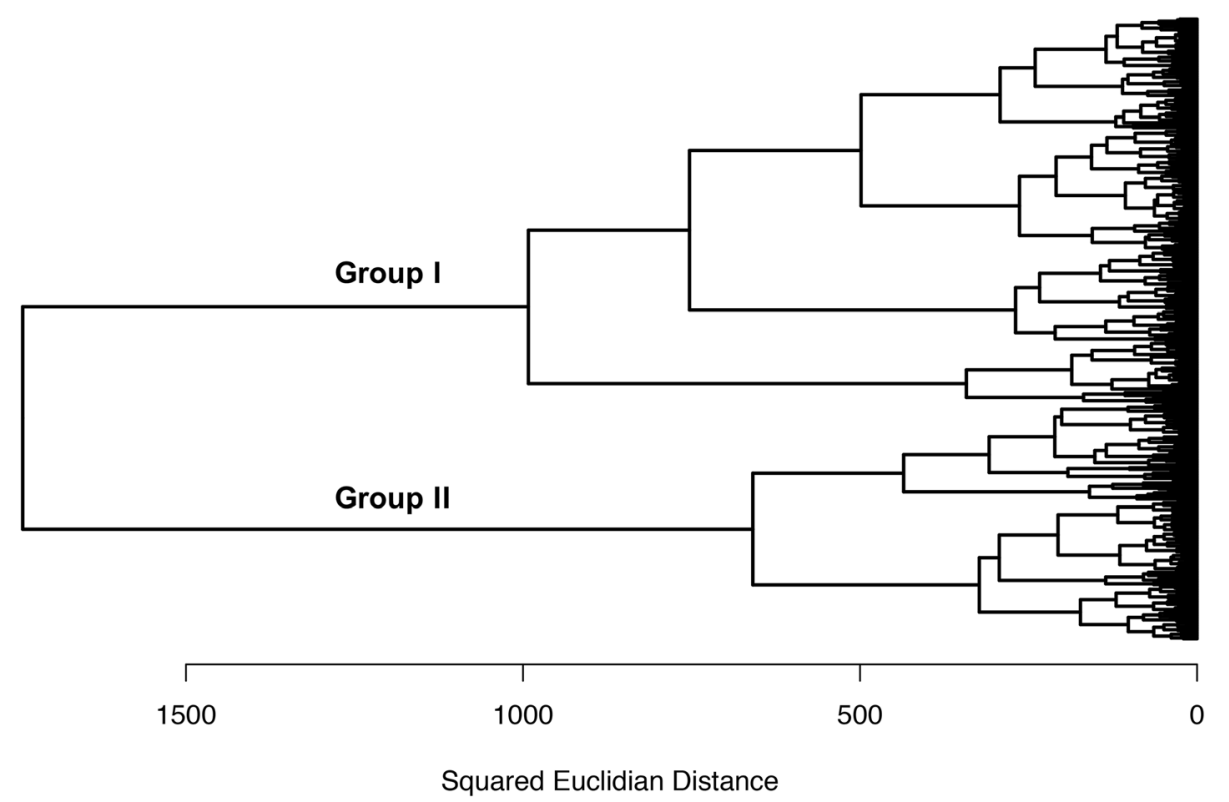

Fig. 2 Hierarchical cluster analysis of the OxG population calculated across 10 phenotypic traits. Three hundred seventy-eight individuals were clustered using Ward's method and the squared Euclidean distance

for 471 palms (62 E. oleifera (O), 31 E. guineensis (G), and 378 (OxG)). The genotyping of the collection detected 131,825 SNPs covering 16 oil palm chromosomes. After filtering, 3776 SNPs with an average of 236 SNPs per chromosome were retained (Additional file 2: Table S2).

\section{Cluster and association analyses}

The neighbor-joining (NJ) analysis of the entire population (471 palms) (Fig. 3a) showed two main groups containing E. oleifera and E. guineensis, as well as three groups within the OxG population, as follows: One group was more similar to E. guineensis, another was more similar to E. oleifera, and the largest group showed an intermediate similarity to both parental species. The three groups in the OxG population represented the classic distribution of crosses between two highly heterozygous diploids ( $\mathrm{Aa} \times \mathrm{Aa}$ ) with a genotypic segregation ratio of 1:2:1.

The PCA analysis of the OxG population (378 hybrids) showed that the first three components comprised approximately $15.47 \%$ of the total variation and allowed the population to be categorized into three groups, thereby supporting the results observed in the NJ tree in accordance with the segregating nature of our population (Fig. 3b).

We performed the association analysis on the 378 OxG hybrids and 3776 SNPs for seven morphological traits and three yield-related traits (Table 1). Twelve SNPs were most significantly associated with the traits measured, based on $p$-values across different genomic regions of the oil palm genome before the false discovery rate (FDR) correction (Table 2). Common SNPs for rachis length (RL) and leaflet per leaf (LXL) were observed, as well as for HT and LA, and between yield and BN, following the results from the phenotypic correlations. The Q-Q plots (Fig. 4) significantly supported the evidence for SNP associations with the traits $(p \leq 0.005)$ and suggested that population stratification in the GWAS model was adequately controlled.

The availability of the oil palm genome sequence [29] enabled the association of specific QTLs with genomic regions on the physical map and the exploration of potential candidate genes and their possible functions. On chromosomes 3, 13, and 15, we identified 10 significant SNPs located on genomic regions harboring genes associated with the morphological-related traits before the FDR correction (Fig. 4 and Table 2). For yield-related traits, we observed two SNPs into two candidate genes on chromosomes 5 and 10, which were non-significant after carrying out the FDR correction (Fig. 4, Table 2). We evaluated whether the SNPs found in association with traits were in chromosomes with a larger number of markers to assess whether our results could have arisen from biases in the genotyping. The associated SNPs found in this study (chromosomes 3, 5, 10, 13, and 15) were not located in the chromosomes with higher numbers of SNPs as identified by the GBS approach (Additional file 2: Table S2).

The pair-wise linkage disequilibrium (LD) between the SNPs of the chromosomes that were presented in the 


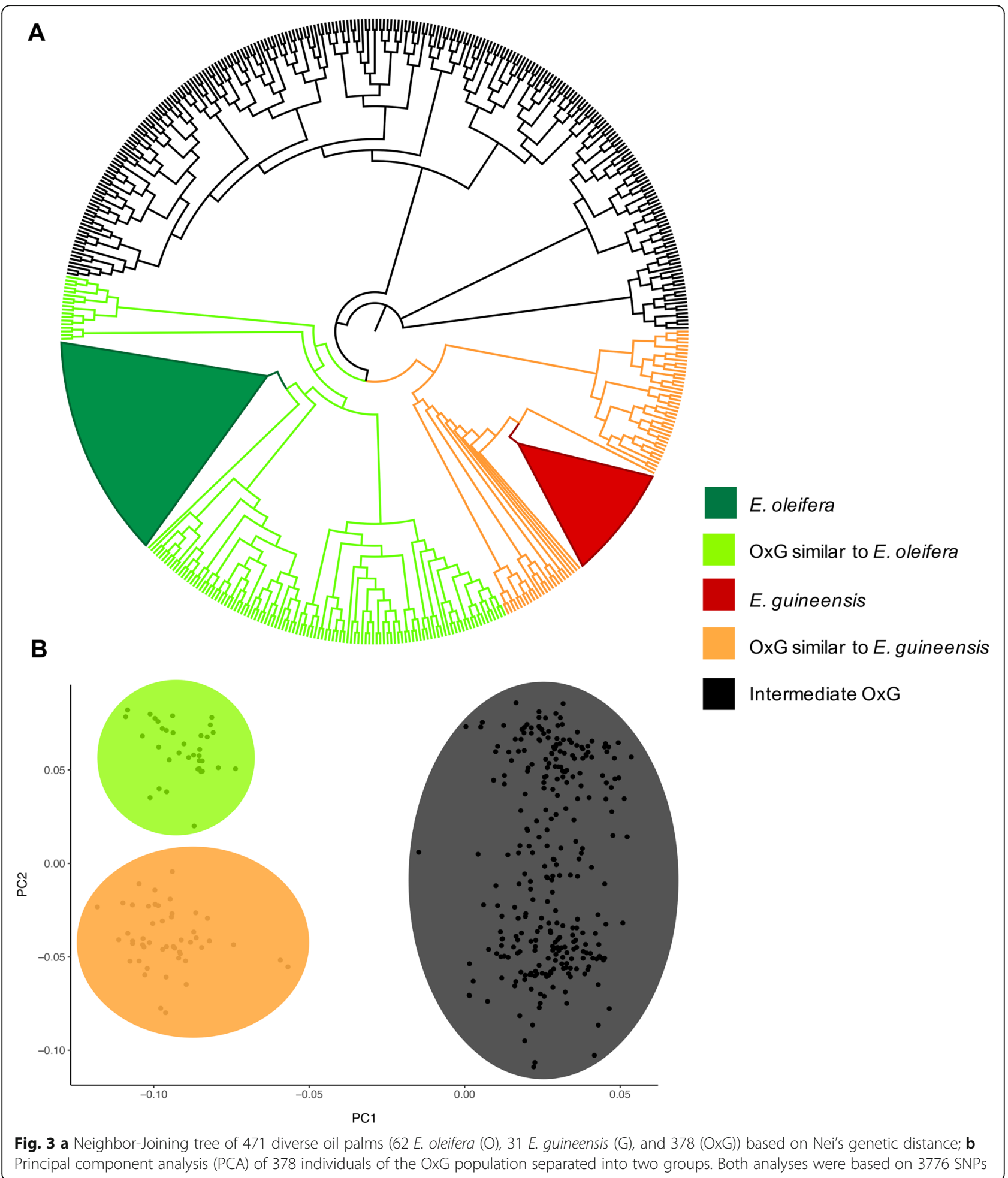

genomic regions associated with the evaluated traits is illustrated in Additional file 4: Figure S2. The LD blocks were small for all chromosomes shown, which was expected, considering the out-crossing nature of the species.

\section{Discussion}

Improving oil quality and increasing yield per hectare in oil palm are major concerns in the oil processing industry. The Corporación Colombiana de Investigación Agropecuaria (Agrosavia), a non-profit government 


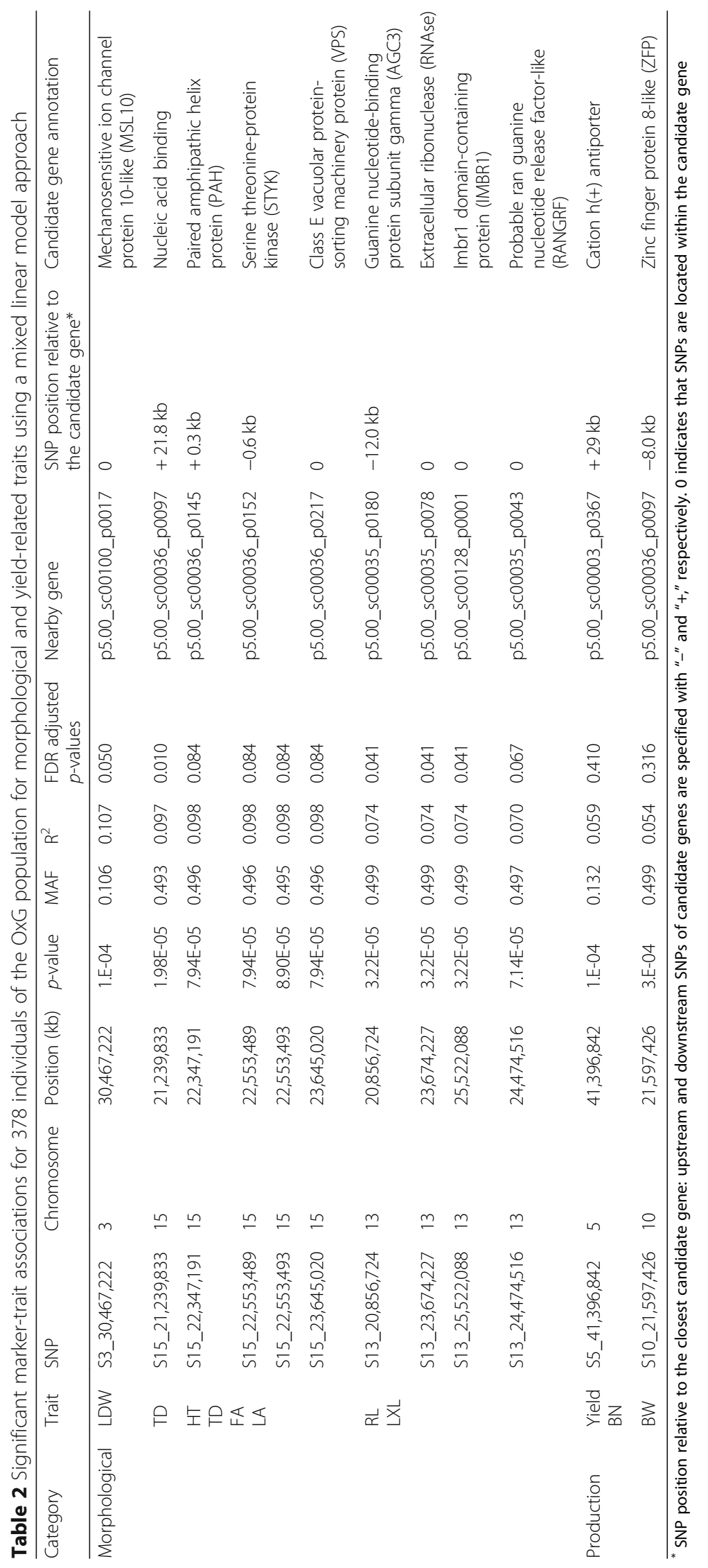




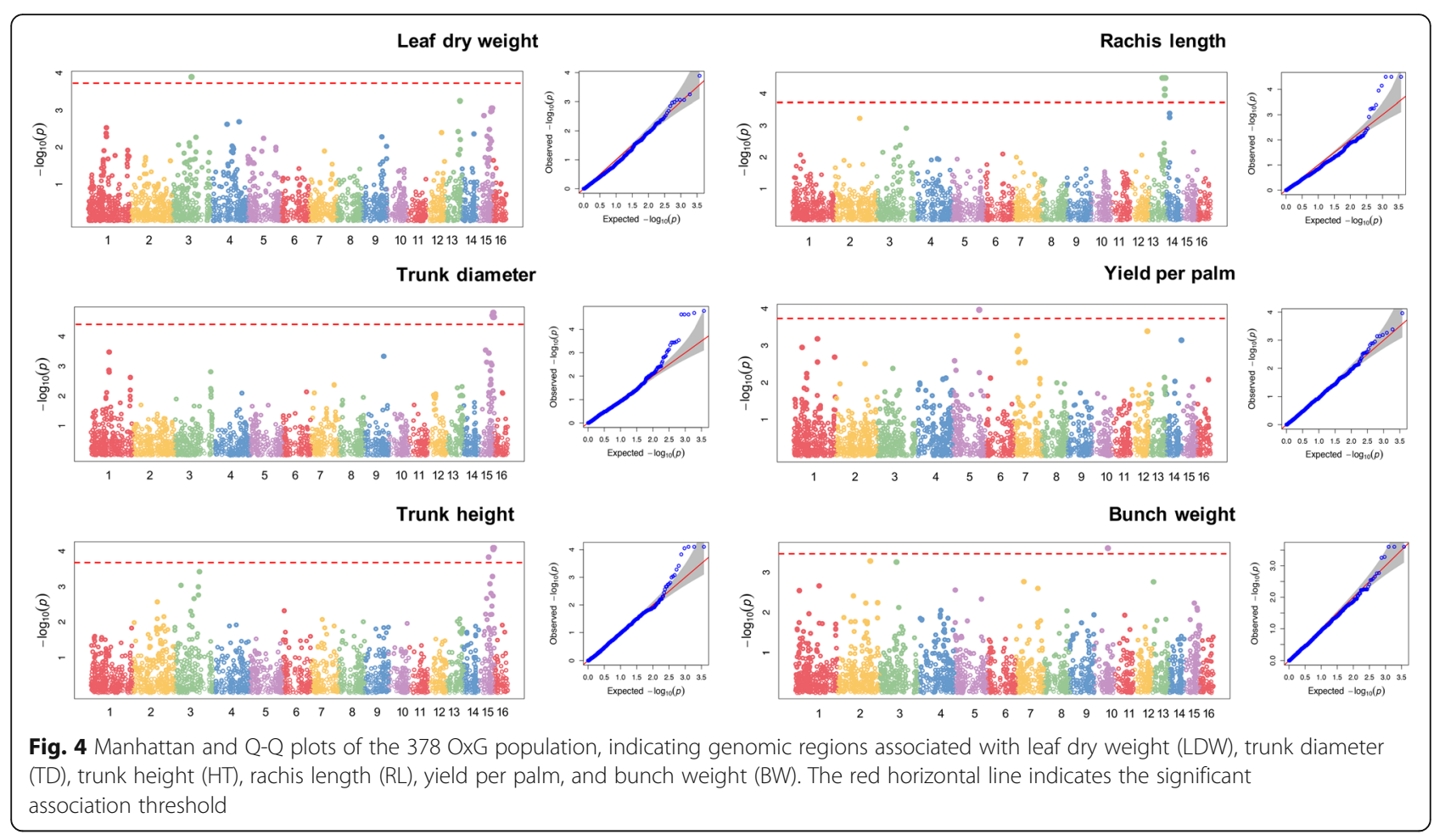

research institution, is committed to delivering solutions to farmers, incorporating cultivars developed from breeding programs that include the oil palm. Its strategy has focused on developing interspecific OxG that present heterosis in traits such as resistance to diseases, fruit number, fruit weight, leaf length, and trunk diameter [30]. To our knowledge, this study is the first GWAS analysis of an OxG population.

\section{Phenotypic data}

Correlation analysis results for yield-related traits indicated that BN could have the potential to be a better selection criterion for production compared to BW in the OxG population. In our study, no significant correlations between yield and leaf-related traits (FA, LA, LDW, LXL, RL) were found; however, a previous study in $E$. oleifera and with OxG hybrids found that $\mathrm{BN}$ can be higher than the number of leaves, but only at the time when oil palms are producing multiple inflorescences [31]. Increases in $\mathrm{BN}$ and $\mathrm{BW}$ are also expected to correlate with increased mesocarp and kernel oil yields, as shown in other oil palm germplasm studies [32]. Future studies directed to improve the oil yields should be conducted considering the importance of this aspect of oil palm breeding.

\section{Association analysis}

In the current study, we generated sequencing data using GBS, a technology developed for crop plants [19]. GBS relies on restriction enzymes to generate a reduced representation of locations spread throughout the genome to decrease its complexity and rapidly genotype samples using interspaced SNP markers [33], that could be linked to candidate genes responsible for important traits. For this reason, GBS has gained popularity in crop research and plant breeding due to its high throughput and lowcost genotyping, being suitable for population studies, germplasm characterization, genetic improvement, and trait mapping in a variety of diverse organisms [34].

With the association mapping, 12 genomic regions (SNPs) related to 10 morphological and yield-related traits were identified (Table 2). However, only five regions associated with LDW, TD, RL, and LXL remained significant $(p \leq 0.05)$ after the FDR correction was performed. Importantly, the SNPs found to have a statistically significant association with the trait are not necessarily the causal DNA variant, that is, a variant that has a direct effect. The association only signifies that the SNP locus harbors a causal variant in LD with the SNP identified by the GWAS.

The small LD blocks in the heat map analysis could suggest that the causal regions are located near to the most significant SNPs. Thus, the identified SNP in this study serves as a signpost defining an interval in the genome for which one must do follow-up studies to determine the causal variant(s).

Therefore, we describe the five most significant regions and the genes located within those regions that 
might be potential candidate genes involved in the expression of the phenotypic traits evaluated in this study. For morphological traits, a significant association was found for LDW on chromosome 3, explaining 10\% of the phenotypic variation. The most significant SNP in this region was located in a mechanosensitive (MS) ion channel protein 10-like (MSL10) gene. It has been proposed that the MS ion channels in plants play a wide array of roles, from facilitating the perception of touch and of gravity to regulating the osmotic homeostasis of intracellular organelles [35]. In addition, mechanoperception genes are essential for the growth and development of normal cells and tissue as well as for the proper responses to an array of biotic and abiotic stresses [36]. A second significant region was identified associated with TD on chromosome 15 that contains a gene involved in nucleic acid binding that has a $\mathrm{C} 2 \mathrm{H} 2$-type zinc finger domain. It has been proposed that the $\mathrm{C} 2 \mathrm{H} 2-\mathrm{ZF}$ gene family is involved in the formation of wood and in shoot and cambium development in species such as poplar, and that it also plays a role in stress and phytohormone responses [37].

For RL and LXL traits, QTLs have been reported on chromosomes 2, 4, 10, and 16 [32]. In our study, three SNPs were associated with three different candidate genes for RL on chromosome 13. The SNP S13_20,856, 724 is the closest to the $A G C 3$ gene and encodes different $\mathrm{G}$ proteins. These have been reported to be involved in a wide range of developmental and physiological processes, and therefore have a potential for facilitating yield improvement in crops such as rice [38]. The second significant association was found with the SNP S13 23,674,227, which is located in an extracellular ribonuclease gene (RNase gene). The RNase genes in plants have been studied for years and play an essential role in plant defense [39] and development due to their ability to modify RNA levels and thereby influence protein synthesis [40]. Finally, the SNP S13_25,522,088 was also significantly associated with RL and LXL, but further studies are necessary to determine its role, if any, in regulating these traits.

Seven SNPs were no longer significant after the FDR correction, possibly due to the reduced sample size used. QTL and association studies are limited by the relatively small mapping population sizes, resulting in low statistical power and thus rendering small or even medium-effect QTLs that are statistically non-significant and difficult to detect. Such statistically underpowered populations may also suffer from severe inflation of effect size estimates (the so-called Beavis effect) [41]. Hence, increasing the population size and marker density is required to enable estimations that are unbiased by the Beavis effect and achieve higher statistical power [41-43]; nonetheless, for perennial populations (long generation time) with limited offspring numbers, the size increase would require a considerable investment.

For the oil palm, the harvesting of fruit bunches after the palm has reached a certain age is an arduous task due to the height of the trunk. For this reason, genotypes with reduced HT and TD are preferred among oil palm farmers. Likewise, a larger foliar area (dependent on RL and LDW) is related to greater photosynthetic production, which could be involved in higher productivity. Nevertheless, most importantly, increasing the number and weight of fruits means a higher productivity per palm and therefore a higher income for farmers. For this reason, leveraging QTLs or genes related to these traits (such the ones we identify in this study) could contribute to the development of plant breeding strategies, such as marker-assisted selection that help with the selection of promising accessions in earlier stages (i.e., greenhouse conditions) and therefore reduce the breeding cycle. There is need for further work that focuses on the biological functions of the set of potential candidate genes found in our research since the correlations we have identified in our association study cannot, as yet, be dubbed as causations.

\section{Conclusions}

Our study is the first to report five significant genomic regions associated with morphological and yield-related traits based upon GWAS on an interspecific OxG oil palm population. Genes whose functional annotations are potentially related to the corresponding traits are located within these regions and, therefore, these might represent candidate genes for the QTLs. Our results will provide the groundwork for the development of markerassisted breeding in the oil palm and will serve as a strong base for future functional studies to determine the drivers of high yield production.

\section{Methods \\ Plant material}

A total of 471 diverse oil palms (62 E. oleifera (O) accessions, 31 E. guineensis (G) accessions, and $378 \mathrm{OxG}$ hybrids) from the El Mira and La Libertad research centers of the Corporación Colombiana de Investigación Agropecuaria (Agrosavia) [44], were included in this research. The OxG population was obtained through eight different crossings (eight different $E$. oleifera accessions as female progenitors were crossed with one $E$. guineensis accession as the male progenitor); however, the parents of these crossings are currently dead. Details of the crosses and the origins of individuals are given in Additional file 1: Table S1. The plant material belongs to the National Germplasm Collection of Colombia maintained by Agrosavia. All samples were collected following national regulations. 


\section{Phenotyping}

Phenotypic data were collected for the subset of 378 OxG hybrids, that were planted in a quincunx or triangular system with $10 \mathrm{~m}$ between the plants at El Mira research center of Agrosavia in Tumaco, Colombia. Plants were randomly distributed using a completely randomized block design with four blocks.

A total of 10 traits (Table 1) distributed between two categories (morphological and yield-related), were evaluated as follows: i) Morphological category (seven traits): Trunk Diameter (TD, trunk circumference at the midsection), Trunk Height (HT, distance between the lowest green leaves and the fruit), Rachis Length (RL, measured on fully expanded leaves), Leaf Dry Weight (LDW, mean dry weight per leaf multiplied by the number of leaves produced), Foliar Area (FA, mean area per leaf multiplied by the number of leaves per palm), Leaf Area (LA, mean area per leaf), and Leaflet per Leaf (LXL, length of the largest leaflet). ii) Yield-related category (three traits): Bunch Weight (BW, the weight of fruits during harvest), Bunch number ( $\mathrm{BN}$, the number of fruits per palm during harvest), and Yield per Palm (Yield, kg of fruits per palm per year). Each trait was measured according to the methodology presented by Corley et al. [45] and Breure [46].

\section{Statistical analysis of phenotypic data}

The correlations among traits were calculated using Pearson's correlation coefficient $(r)$ with $p \leq 0.05$. To assess the relationships between the studied traits, a principal component analysis (PCA) was carried out. Finally, a hierarchical cluster analysis using Ward's method was carried out to analyze the relationships between hybrids. Differences between clusters by trait were established using a $t$-test with $p \leq 0.0001$. All statistical analyses were performed using the R v3.42 software [47].

\section{Genotyping}

Genomic DNA of 471 palms was extracted from leaf tissue using the DNeasy Plant Mini Kit (QIAGEN, Germany). The DNA quality was estimated using the HindIII enzyme and visualized by electrophoresis on $2 \%$ agarose gels. The GBS libraries were constructed with the methylation-sensitive restriction enzyme PstI (CTGC AG). Sequencing was performed with 100-bp single-end reads using the Illumina HiSeq 2000 platform (Illumina Inc., United States) at the Institute of Genomic Diversity (Cornell University, Ithaca, NY, United States).

\section{SNP discovery and data processing}

Illumina reads were demultiplexed using the standard pipeline from Tassel v4.5.9 software [48]. Then, reads were mapped to the oil palm reference genome of E. guineensis [49] using Bowtie2 [50] employing the very- sensitive option. SNP calling was performed using the following parameters: minor allele frequency (MAF) < $5 \%$, minimum locus coverage (mnLCov) of 0.9 , minimum site coverage (mnScov) of 0.7 and minimum taxon coverage (mnTCov) of 0.5. Finally, SNPs were filtered using the VCFtools v0.1.13 software [51] to remove 95\% of missing data and to retain biallelic SNPs.

\section{Cluster and marker-trait association analyses}

The clustering analysis for all 471 oil palms was performed by a neighbor-joining algorithm using Tassel v4.3.5 [48] and was visualized with Figtree v1.4.0 [52]. The population structure for the 378 OxG hybrids was evaluated through a PCA using the SNPrelate [53] procedure in the $\mathrm{R}$ package. Associations between molecular markers and phenotypic data were computed using the mixed linear model in the software GAPIT (Genome Association and Prediction Integrated Tool) [54]. To avoid any possible bias caused by population structure, we included the first five principal components of the PCA and a relatedness (kinship) matrix from GAPIT in the mixed linear model. Quantile-quantile $(\mathrm{Q}-\mathrm{Q})$ plots using the observed $-\log _{10} p$-values and the expected $-\log _{10} p$-values were generated to study the appropriateness of the GWAS model. A false discovery rate (FDR) [55] was used to correct for spurious associations.

The heat map of the linkage disequilibrium (LD) was generated with a custom script by plotting pairwise $R^{2}$ values against the physical distance (base pairs) between markers on the same chromosome.

\section{Potential candidate gene identification}

The physical positions of the SNP markers were obtained from the Genomsawit website of the International Malaysian Oil Palm Genome Programme (http:// gbrowse.mpob.gov.my/fgb2/gbrowse/Eg5_1/). Gene annotations under the candidate gene regions were established using published genome information for $E$. guineensis [49]. The flanking sequences of SNPs to assign the putative biological functions of significant SNP markers associated with the traits were queried against databases, such as HMMER (https://www.ebi.ac.uk/Tools/ hmmer/) and NCBI (http://www.ncbi.nlm.nih.gov/), and those of the European Molecular Biology Laboratory (http://www.ebi.ac.uk/) and the European Nucleotide Archive (http://www.ebi.ac.uk/ena).

\section{Supplementary information}

Supplementary information accompanies this paper at https://doi.org/10. 1186/s12870-019-2153-8.

Additional file 1: Table S1. List of the OxG and parentals oil palms used in this study. 
Additional file 2: Table S2. SNPs identified per chromosome using the reference genome of $E$. guineensis.

Additional file 3: Figure S1. Box plots of the two cluster groups for all morphological and yield-related traits. ${ }^{*}=$ significant at $p \leq 0.0001$, ns $=$ non-significant.

Additional file 4: Figure S2. Linkage disequilibrium (LD) heat map for each chromosome with significant associated SNPs in an OxG population.

\section{Abbreviations}

AFLP: Amplified Fragment Length Polymorphism; BN: Bunch Number; BW: Bunch Weight; FA: Foliar Area; FDR: False-Discovery-Rate; GBS: Genotyping-By-Sequencing; GWAS: Genome-Wide Association Studies; HT: Trunk Height; LA: Leaf Area; LD: Linkage Disequilibrium; LDW: Leaf Dry Weight; LXL: Leaflet Per Leaf; PCA: Principal Component Analysis; QTL: Quantitative Trait Loci; RFLP: Restriction Fragment Length Polymorphism; RL: Rachis Length; SD: Standard Deviation; SNP: Single Nucleotide Polymorphism; SSR: Simple Sequence Repeat; TD: Trunk Diameter

\section{Acknowledgments}

The authors would like to acknowledge William Tolosa for his support during sample collection, Jhon Berdugo for his support of the data analysis process, Marco Antonio Lopez for providing the script for the LD heat map analysis, and Roxana Yockteng for her support during the elaboration of the neighbor-joining analysis. The authors thank Joanna Kelley for her assistance in revising the final version of the manuscript. The access to the oil palm accessions complies with the genetic resource agreement for scientific research without commercial interest No. 74, signed between Agrosavia and Ministerio de Agricultura y Desarrollo Rural (MADR) of Colombia.

\section{Authors' contributions}

$\angle S B, F E E R$, and SBP conceptualized and conceived the project and its components. SBP, PDD, GAGM, FEER, JAOG, and LPM collected hybrids and trait data. JAOG and GAGM carried out the genotypic and phenotypic analysis with the supervision of OEC. JAOG and GAGM wrote the manuscript, and LSB, OEC, and FEER corrected and edited it. All authors contributed to drafting and reviewing the manuscript and read and approved the final version of the manuscript.

\section{Funding}

The publication of this article has been funded by TV-17, supported by Ministerio de Agricultura y Desarrollo Rural de Colombia (MADR). The funding entities had no role in the study design, data collection, and analysis, interpretation, decision to publish, or preparation of the manuscript.

\section{Availability of data and materials}

The datasets used and analyzed during the current study are available from the corresponding author upon reasonable request.

\section{Ethics approval and consent to participate}

The research on plant material, including its collection, complies with institutional and national guidelines.

\section{Consent for publication}

Not applicable.

\section{Competing interests}

The authors declare that they have no competing interests.

\section{Author details}

'Tibaitatá Research Center, Corporación Colombiana de Investigación Agropecuaria, Agrosavia, Bogotá, Colombia. ${ }^{2}$ Palmira Research Center, Corporación Colombiana de Investigación Agropecuaria, Agrosavia, Palmira, Colombia. ${ }^{3}$ School of Biological Sciences, Washington State University, Pullman, WA, USA.
Received: 31 July 2019 Accepted: 21 November 2019

Published online: 03 December 2019

\section{References}

1. Murphy D. Oil palm: future prospects for yield and quality improvements; 2009 .

2. Pacheco P, Gnych S, Dermawan A, Komarudin H, Okarda B. The palm oil global value chain: implications for economic growth and social and environmental sustainability. Bogor: Center for International Forestry Research (CIFOR); 2017.

3. Barcelos E, de Rios SA, Cunha RNV, Lopes R, Motoike SY, Babiychuk E, et al. Oil palm natural diversity and the potential for yield improvement. Front Plant Sci. 2015;6:190. https://doi.org/10.3389/fpls.2015.00190.

4. Srestasathiern P, Rakwatin P. Oil palm tree detection with high resolution multi-spectral satellite imagery. Remote Sens (Basel). 2014;6:9749-74. https:// doi.org/10.3390/rs6109749.

5. Escobar R, Alvarado A. Estrategias para la producción comercial de semillas y clones de palmas de aceite compactas. Rev Palmas. 2004;25:293-305. https://publicaciones.fedepalma.org/index.php/palmas/article/view/1093.

6. Turner PD. Oil palm diseases and disorders: Oxford University Press; 1981. https://books.google.com.co/books?id=mAnyXwAACAAJ.

7. Amblard P, Billotte N, Cochard B, Durand-Gasselin T, Jacquemard JC, Louise $\mathrm{C}$, et al. El mejoramiento de la palma de aceite Elaeis guineensis y Elaeis oleifera por el Cirad-CP. Rev Palmas. 2002;25:306-10.

8. Zambrano JE. Los híbridos interespecíficos Elaeis oleifera HBK. x Elaeis guineensis Jacq. : una alternativa de renovación para la Zona Oriental de Colombia. Rev Palmas. 2004;25:339-49. http://publicaciones.fedepalma.org/ index.php/palmas/article/view/1098.

9. Chinchilla C. Toleracia y resistencia a las pudriciones del cogollo en fuentes de diferente origen de Elaeis guineensis. Rev Palmas. 2007;28:273-84.

10. Moura J. Manejo integrado das pragas das palmeiras. Ilheus: Centro de Pesquisas do Cacau; 2017.

11. Hartley CWS. The oil palm (Elaeis guineensis Jacq.). 2nd ed; 1967.

12. Mayes S, Jack PL, Corley RHV, Marshall DF. Construction of a RFLP genetic linkage map for oil palm (Elaeis guineensis Jacq.). Genome. 1997;40:1 16-22.

13. Purba AR, Noyer JL, Baudouin L, Perrier X, Hamon S, Lagoda PJL. A new aspect of genetic diversity of Indonesian oil palm (Elaeis guineensis Jacq.) revealed by isoenzyme and AFLP markers and its consequences for breeding. Theor Appl Genet. 2000;101:956-61. https://doi.org/10.1007/ s001220051567.

14. Jeennor S, Volkaert H. Mapping of quantitative trait loci (QTLS) for oil yield using SSRs and gene-based markers in African oil palm (Elaeis quineensis Jacq.). Tree Genet Genomes. 2014;10:1-14.

15. Billotte N, Marseillac N, Risterucci A-M, Adon B, Brottier P, Baurens F-C, et al. Microsatellite-based high density linkage map in oil palm (Elaeis guineensis Jacq.). Theor Appl Genet. 2005;1 10:754-65.

16. Seng T-YY, Ritter E, Mohamed Saad SH, Leao L-JJ, Harminder Singh RS, Qamaruz Zaman F, et al. QTLs for oil yield components in an elite oil palm (Elaeis guineensis) cross. Euphytica. 2016;212:399-425. https://doi.org/10. 1007/s10681-016-1771-6.

17. Yadav P, Vaidya E, Rani R, Yadav N, Singh B K. Rai P, et al. Recent perspective of next generation sequencing: applications in molecular plant biology and crop improvement. 2016.

18. Le Nguyen K, Grondin A, Courtois B, Gantet P. Next-generation sequencing accelerates crop gene discovery. Trends Plant Sci. 2019;24:263-74. https:// doi.org/10.1016/.jplants.2018.11.008.

19. Elshire RJ, Glaubitz JC, Sun Q, Poland JA, Kawamoto K, Buckler ES, et al. A robust, simple genotyping-by-sequencing (GBS) approach for high diversity species. PLoS One. 2011;6:1-10. https://doi.org/10.1371/journal.pone. 0019379.

20. Pootakham W, Jomchai N, Ruang-areerate P, Shearman JR, Sonthirod C, Sangsrakru D, et al. Genome-wide SNP discovery and identification of QTL associated with agronomic traits in oil palm using genotyping-bysequencing (GBS). Genomics. 2015;105:288-95. https://doi.org/10.1016/j. ygeno.2015.02.002.

21. Babu BK, Mathur RK, Ravichandran G, Venu MVB. Genome-wide association study (GWAS) for stem height increment in oil palm (Elaeis guineensis) germplasm using SNP markers. Tree Genet Genomes. 2019;15:1-8.

22. Huang $X$, Han B. Natural variations and genome-wide association studies in crop plants. Annu Rev Plant Biol. 2014;65:531-51. https://doi.org/10.1146/ annurev-arplant-050213-035715. 
23. Korte A, Farlow A. The advantages and limitations of trait analysis with GWAS: a review. Plant Methods. 2013;9:29. https://doi.org/10.1186/1746-4811-9-29.

24. Burghardt LT, Young ND, Tiffin P. A guide to genome-wide association mapping in plants. Curr Protoc Plant Biol. 2017;2:22-38. https://doi.org/10. 1002/cppb.20041.

25. Zhang Z, Ersoz E, Lai C-Q, Todhunter RJ, Tiwari HK, Gore MA, et al. Mixed linear model approach adapted for genome-wide association studies. Nat Genet. 2010;42:355. https://doi.org/10.1038/ng.546.

26. FAO - Trade and market division. Oilcrops. 2014. http://www.fao.org/ fileadmin/templates/est/COMM_MARKETS_MONITORING/Oilcrops/ Documents/Food_outlook_oilseeds/Food_Outlook_May_2014_ OILCROPS.pdf.

27. Kurnia JC, Jangam SV, Akhtar S, Sasmito AP, Mujumdar AS. Advances in biofuel production from oil palm and palm oil processing wastes: A review. Biofuel Res J. 2016:3:332-46. https://doi.org/10.18331/BRJ2016.3.1.3.

28. World Growth. The economic benefit of palm oil to Indonesia: World Growth Palm Oil Green Dev Campaign; 2011. February:1-27. http:// worldgrowth.org/site/wp-content/uploads/2012/06/WG_Indonesian_Palm_ Oil_Benefits_Report-2_11.pdf.

29. Sato S, Tabata S, Hirakawa H, Asamizu E, Shirasawa K, Isobe S, et al. The tomato genome sequence provides insights into fleshy fruit evolution Nature. 2012;485:635-41.

30. Bastidas PS. Avances en el desarrollo de materiales genéticos resistentes a la PC. Rev Palmas. 2013;34:135-41.

31. Bastidas S, Hurtado PYL. Evaluación de palmas prolíficas en la especie Elaeis oleífera e híbridos interespecíficos de E. oleífera x E . guineensis; 1993. p. 55-60.

32. Ithnin M, Xu Y, Marjuni M, Serdari NM, Amiruddin MD, Low E-TL, et al. Multiple locus genome-wide association studies for important economic traits of oil palm. Tree Genet Genomes. 2017;13:103. https://doi.org/10.1007/ s11295-017-1185-1.

33. Wickland DP, Battu G, Hudson KA, Diers BW, Hudson ME. A comparison of genotyping-by-sequencing analysis methods on low-coverage crop datasets shows advantages of a new workflow, GB-eaSy. BMC Bioinformatics. 2017;18:586. https://doi.org/10.1186/s12859-017-2000-6.

34. Davey JW, Hohenlohe PA, Etter PD, Boone JQ, Catchen JM, Blaxter ML. Genome-wide genetic marker discovery and genotyping using nextgeneration sequencing. Nat Rev Genet. 2011;12:499-510. https://doi.org/10. 1038/nrg3012

35. Hamilton ES, Schlegel AM, Haswell ES. United in diversity: mechanosensitive ion channels in plants. Annu Rev Plant Biol. 2015;66:113-37. https://doi.org/ 10.1146/annurev-arplant-043014-114700

36. Haswell ES, Peyronnet R, Barbier-Brygoo H, Meyerowitz EM, Frachisse JM. Two MscS homologs provide mechanosensitive channel activities in the Arabidopsis root. Curr Biol. 2008;18:730-4.

37. Liu Q, Wang Z, Xu X, Zhang H, Li C. Genome-wide analysis of $\mathrm{C} 2 \mathrm{H} 2$ zincfinger family transcription factors and their responses to abiotic stresses in poplar (Populus trichocarpa). PLoS One. 2015:10:1-25.

38. Botella JR. Can heterotrimeric G proteins help to feed the world? Trends Plant Sci. 2012;17:563-8. https://doi.org/10.1016/j.tplants.2012.06.002.

39. Sangaev SS, Kochetov AV, Ibragimova SS, Levenko BA, Shumny VK Physiological role of extracellular ribonucleases of higher plants. Russ J Genet Appl Res. 2011;1:44-50. https://doi.org/10.1134/S2079059711010060.

40. Tvorus EK. Plant ribonucleases. Sov Plant Physiol. 1976;23:882-9.

41. Beavis W. QTL analyses: power, precision, and accuracy. In: Molecular dissection of complex traits. Chicago: American Seed Trade Association; 1998. p. 250-66.

42. Klein RJ. Power analysis for genome-wide association studies. BMC Genet 2007:8:58. https://doi.org/10.1186/1471-2156-8-58.

43. Hong EP, Park JW. Sample size and statistical power calculation in genetic association studies. Genomics Inform. 2012;10:117-22. https://doi.org/10. 5808/GI.2012.10.2.117.

44. SB P, EAP R, RR C. Genealogía del germoplasma de palma de aceite (Elaeis guineensis Jacq.) del proyecto de mejoramiento genético de Corpoica. Rev Palmas. 2003;24. https://publicaciones.fedepalma.org/index.php/palmas/ article/view/950

45. Corley RHV, Hardon JJ, Tan GY. Analysis of growth of the oil palm (Elaeis guineensis Jacq.) I. estimation of growth parameters and application in breeding. Euphytica. 1971;20:307-15. https://doi.org/10.1007/BF00056093.

46. Breure CJ. Factors associated with the allocation of carbohydrates to bunch dry matter production in oil palm (Elaeis quineensis Jacq.)

Landbouwuniversiteit; 1987.
47. R development core team. R: a language and environment for statistical computing. Vienna: R Foundation for Statistical Computing; 2008. http:// www.r-project.org.

48. Bradbury PJ, Zhang Z, Kroon DE, Casstevens TM, Ramdoss Y, Buckler ES. TASSEL: software for association mapping of complex traits in diverse samples. Bioinformatics. 2007;23:2633-5. https://doi.org/10.1093/ bioinformatics/btm308.

49. Singh R, Ong-Abdullah M, Low E-TL, Manaf MAA, Rosli R, Nookiah R, et al. Oil palm genome sequence reveals divergence of interfertile species in old and new worlds. Nature. 2013;500:335. https://doi.org/10.1038/nature12309.

50. Langmead B, Trapnell C, Pop M, Salzberg SL. Ultrafast and memory-efficient alignment of short DNA sequences to the human genome. Genome Biol. 2009;10:R25. https://doi.org/10.1186/gb-2009-10-3-r25.

51. Danecek P, Auton A, Abecasis G, Albers CA, Banks E, DePristo MA, et al. The variant call format and VCFtools. Bioinformatics. 2011:27:2156-8. https://doi. org/10.1093/bioinformatics/btr330.

52. Rambaut A. FigTree: tree figure drawing tool version 1.4.2. 2014. http://tree. bio.ed.ac.uk/software/figtree.

53. Zheng X, Levine D, Shen J, Gogarten SM, Laurie C, Weir BS. A highperformance computing toolset for relatedness and principal component analysis of SNP data. Bioinformatics. 2012;28:3326-8. https://doi.org/10.1093/ bioinformatics/bts606

54. Lipka AE, Tian F, Wang Q, Peiffer J, Li M, Bradbury PJ, et al. GAPIT: genome association and prediction integrated tool. Bioinformatics. 2012;28:2397-9. https://doi.org/10.1093/bioinformatics/bts444.

55. Benjamini $Y$, Hochberg $Y$. Controlling the false discovery rate: a practical and powerful approach to multiple testing. J R I State Dent Soc. 1995;57: 289-300

\section{Publisher's Note}

Springer Nature remains neutral with regard to jurisdictional claims in published maps and institutional affiliations.

Ready to submit your research? Choose BMC and benefit from:

- fast, convenient online submission

- thorough peer review by experienced researchers in your field

- rapid publication on acceptance

- support for research data, including large and complex data types

- gold Open Access which fosters wider collaboration and increased citations

- maximum visibility for your research: over $100 \mathrm{M}$ website views per year

At BMC, research is always in progress.

Learn more biomedcentral.com/submission 